\title{
Analiza fizikalnih lastnosti šotnega substrata
}

\author{
Tilen ZAMLJEN ${ }^{1,2}$, Ana SLATNAR ${ }^{1}$, Vesna ZUPANC ${ }^{1}$
}

Received August 25, 2020; accepted November 26, 2020. Delo je prispelo 25. avgusta 2020, sprejeto 26. novembra 2020.

\section{Analiza fizikalnih lastnosti šotnega substrata}

Izvleček: Šotni substrat je glavni substrat, ki se v rastlinski pridelavi uporablja predvsem za vzgojo sadik vrtnin in okrasnih rastlin. Šotni substrat ima dobre vodo zadrževalne lastnosti, majhno maso, nizek pH ter nima bolezni in škodljivcev. Predvsem vodo zadrževalne lastnosti so pomembne za optimizacijo namakanja in s tem porabo vode pri gojenju rastlin. Preverili smo vodo zadrževalne lastnosti neuporabljenega in rabljenega šotnega substrata ter različne mešanice substratov (šota $\mathrm{z}$ dodatki) in pojav vodoodbojnosti, saj le-ta vpliva na sprejem vode $\mathrm{v}$ substrat. Analizirane mešanice neuporabljenega šotnega substrata $\mathrm{z}$ dodatki so zadržale med $3,4 \%$ in $18,4 \%$ več vode kot rabljene substratne mešanice. Dnevne izgube vode so pri rabljenih substratnih mešanicah, ob izhodiščno manjši vsebnosti vode ob polnem nasičenju, manjše. Pri neuporabljenem šotnem substratu je bila pri tenziji med 10 in $33 \mathrm{kPa}$ količina vode med 25 in $32 \%$. Točka venenja (TV) za neuporabljen šotni substrat je med 300 in $1500 \mathrm{kPa}$ oziroma med 15 in $18 \%$. Šotni substrat ima širok interval poljske kapacitete ter hiter prehod iz območja poljske kapacitete do točke venenja (med 7 in $10 \%$ ). Ob sušenju vodoodbojnost tako neuporabljenega kot rabljenega šotnega substrata narašča.

Ključne besede: šota; fizikalne lastnosti substratov; vodoodbojnost; substrat; tenzija; vsebnost vode
1 Univerza v Ljubljani, Biotehniška fakulteta, SI-1000 Ljubljana

2 Korespondenčni avtor, e-naslov: tilen.zamljen@bf.uni-lj.si
Evaluation of soil physical properties of peat substrate

Abstract: Peat substrate is the main substrate for plant production, mainly for the cultivation of vegetable seedlings and ornamental plants. Peat has good water retention properties, low mass, low $\mathrm{pH}$ and is free from diseases and pests. The water retention properties are particularly important for optimizing irrigation and thus water consumption in plant production. We investigated the water retention properties of unused and used peat substrate and various mixtures with additives, as well as the occurrence of water repellency, as this influences water absorption into the substrate. Unused peat substrate and different mixtures retained between $3.4 \%$ and $18.4 \%$ more water than the used substrate. The daily water losses are lower for the used substrates that initially contain lower water content at full saturation. At tensions between 10 and $33 \mathrm{kPa}$, the unused peat substrate contained between $25 \%$ and $32 \%$ water. The wilting point (WP) for unused peat substrate (tension between 300 and $1500 \mathrm{kPa}$ ) was between 15 and $18 \%$. Peat substrate has a wide interval of field capacity and the transition from the field capacity to wilting point is fast (change in water content between $7 \%$ and $10 \%)$. After drying, the water repellency of both unused and used peat substrates increased.

Key words: peat; physical properties of substrates; water repellency; substrate; tension; water content 


\section{UVOD}

Substrat, kot je šota, se v rastlinski pridelavi pogosto uporablja zaradi dobrih vodo zadrževalnih lastnosti, strukturne stabilnosti, nizkega $\mathrm{pH}$ (enostavno prilagajanje potrebam rastlin), odsotnosti patogenov, plevelov in majhne mikrobne aktivnosti (Raviv in Lieth, 1979). Fizikalno kemijske lastnosti, kot so nasipna gostota, vodo zadrževalne lastnosti, $\mathrm{pH}$, kationska izmenjalna kapaciteta in vsebnost hranil, nihajo med substrati, zato imajo lahko občuten vpliv na rast in razvoj rastlin ter njihovo preskrbo s hranili in vodo (Grover in Baldock, 2013). Posledično vsak substrat ni primeren generalno za vse tehnologije vzgoje rastlin $\mathrm{v}$ hortikulturi.

Šota je eden izmed najbolj razširjenih substratov na svetu (77 \% do $80 \%$ substratov za rastlinsko pridelavo vsebuje šoto) (Handrek in Black, 2002). Šota nastane $\mathrm{z}$ delno razgradnjo šotnih in ostalih mahov ter drugih močvirskih rastlin, predvsem trav, šašev, ločkov in drugih vrst, ki rastejo $\mathrm{v}$ močvirnatih tleh, kjer je nizek pH in so anaerobne razmere (ni prisotnosti kisika) (Grover in Baldock, 2013). Glede na stopnjo razgradnje šote in vodne razmere, $\mathrm{v}$ katerih nastane, ločimo svetlo in temno šoto. Na območjih, kjer je debel organski horizont in plitva mineralna plast, nastaja svetla ali bela šota (do $30 \mathrm{~cm}$ globine), medtem ko temna šota nastaja od $30 \mathrm{~cm}$ do $200 \mathrm{~cm}$ globine. $Z$ globino se spreminjajo fizikalne in kemijske lastnosti šote. Temna šota ima $\mathrm{v}$ primerjavi $z$ belo šoto večjo poroznost in večjo zadrževalno sposobnost vode (zadrži 15-kratno količino vode svoje mase, svetle le 4 do 5 -kratno količino). Svetla šota izgubi ob ponovni navlažitvi med 70 do $90 \%$ volumna, temna šota pa med 10 in $25 \%$ volumna. Slaba stran uporabe šote je, da se zaradi pridobivanja uničuje močvirske ekosisteme. Obnavljanje šotišč je prepočasno za naše potrebe, saj 1 meter šote nastaja 1000 let. Iz šotišč se sprosti ogromno ujetega $\mathrm{CO}_{2}$, kar pospešuje klimatske spremembe (Schwärzel in sod., 2002).

Šota ima majhno vsebnost hranil, nizek $\mathrm{pH}$, majhno volumsko gostoto in dobro zračnost. Zaradi teh lastnosti je kot rastni substrat primerna za gojenje mnogih rastlinskih vrst. Šota je neobnovljiv vir, tako se v zadnjih desetletjih iščemo primerne nadomestke, kot so npr. kamena volna, vermikulit, perlit, kokosova vlakna, lesna vlakna. $Z$ novimi substrati in mešanicami želimo najti substrate brez ali z zelo majhno vodoodbojnostjo, boljšimi vodo zadrževalnimi lastnostmi in katerih raba ima majhen ekološkega vpliv (Giancarlo, 2015).

Fizikalne lastnosti substratov (šote) so pomembne pri namakanju rastlin v kmetijski pridelavi, zato smo analizirali fizikalne lastnosti šote in šotnih mešanic, $\mathrm{z}$ namenom določitve obrokov namakanja ter boljšega razumevanja obnašanja substrata $\mathrm{v}$ procesu osuševanja. Nadalje so nas zanimale morebitne spremembe fizikalnih lastnosti ob ponovni uporabi šotnega substrata in mešanic.

\section{MATERIALI IN METODE}

\subsection{ZASNOVA POSKUSA}

Analizirali smo lastnosti neuporabljenega in uporabljenega šotnega substrata (Klasmann N3), ki je sestavljen iz severno nemške črne šote in baltske bele šote. Namenjen je gojenju sadik tako $\mathrm{v}$ zelenjadarstvu kot v okrasnem vrtnarstvu (Humko, 2020). Za analizo neuporabljenega šotnega substrata smo odprli novo vrečo šotnega substrata. Za uporabljen šotni substrat smo uporabili šotni substrat iz lončnega poskusa s čiliji (Zamljen in sod., 2020. Uporabljen šotni substrat smo otresli iz koreninskega sistema rastlin in ga presejali skozi $4 \mathrm{~mm}$ sito, da je bilo $\mathrm{v}$ njem čim manj rastlinskih ostankov (korenin). Vse vzorce smo pospravili v papirnate vrečke. Izenačen neuporabljen in uporabljen šotni substrat $\mathrm{z}$ enako vlažnostjo smo zatehtali $\mathrm{v}$ plastične lončke $(\Phi 12 \mathrm{~cm}) \mathrm{s}$ prostornino 0,571 litra. Poleg neuporabljenega in uporabljenega šotnega substrata smo za analizo pripravili tudi mešanice šotnega substrata in različnih dodatkov (kamena volna, vermikulit in agrogel). Kombinacije substrata in dodatkov so bile (i) čista šota (kontrola), (ii) šota položena na $2 \mathrm{~cm}$ disk kamene volne, (iii) mešanica 80 volumskih odstotkov (\%) šote in $20 \%$ kameno volnatih kosmov, (iv) mešanica $80 \%$ šote in $20 \%$ vermikulita ter (v) šota $\mathrm{z}$ dodanim agrogelom $(0,25 \%)$. Mešanice substratov so bile tehtane v plastičnih lončkih $(\varphi=12 \mathrm{~cm}) \mathrm{s}$ prostornino 0,571 litra. Mešanice substratov smo napolnili v petih ponovitvah, jih navlažili do nasičenja in stehtali. Spremljali smo, kako hitro voda odteče ali izhlapi iz substrata. Lonce s substrati (neuporabljen in uporabljen) smo sušili na konstantni temperaturi $\left(25^{\circ} \mathrm{C}\right)$ do konstante mase. Vsak substrat se je dvakrat dnevno stehtalo. Iz podatkov smo izračunali maso ob polnem nasičenju in povprečno dnevno izgubo vode iz substrata ob postopnem izsuševanju.

\subsection{LASTNOSTI ŠOTNIH SUBSTRATOV IN DO- DATKOV}

Kamena volna se $\mathrm{v}$ hortikulturi uporablja $\mathrm{v}$ obliki plošč ali kock. Na tržišču je dostopna tudi v obliki kosmov, ki se uporabljajo predvsem kot dodatek substra- 
tom. Naredijo jo iz mešanice treh kamnin (60\% diabaz, $20 \%$ apnenec in $20 \%$ koks), ki jo raztopijo pri $1600{ }^{\circ} \mathrm{C}$ (Raviv in Lieth, 2008). Pri ohlajanju se tvorijo tanka vlakna. Kamena volna je lahek material, z majhno gostoto $0,05-0,1 \mathrm{~g} \mathrm{~cm}^{-3}$. Poroznost kamene volne je med $92 \%$ in 98 \% (Smith, 1987, 1998; Kipp in sod., 2000). Velika dostopnost vode pri majhnih tenzijah (pod 5 $\mathrm{kPa}$ ) omogoča rastlini dobro preskrbljenost $\mathrm{z}$ vodo (Kipp in sod., 2000). Sposobnost zadrževanja vode pri kameni volni je specifična, saj se vsebnost vode naglo zmanjša, že pri tenzijah nad $5 \mathrm{kPa}$. Značilno za plošče iz kamene volne je izjemno omočeno dno (le 4 \% zraka) in suho površje plošče (Smith, 1987).

Vermikulit je naravni mineral, vsebuje vodo med plastmi. Substrat vermikulit se segreje na $1000^{\circ} \mathrm{C}$, da se voda upari in poveča delež por, kar daje substratu značilno obliko, majhno maso ter veliko poroznost. Gostota delcev je $0,9 \mathrm{~g} \mathrm{~cm}^{-3}$ in nasipno gostoto med 0,07 in $1 \mathrm{~g} \mathrm{~cm}^{-3}$. Dobro zadržuje vlago (do $70 \%$ lastnega volumna). Pogosto se ga uporablja kot dodatek drugim substratom. Vermikulit se proizvaja $\mathrm{v}$ različnih velikostih delcev, najpogosteje v velikostih 0-2 mm, 2-4 mm in 4-8 $\mathrm{mm}$. Občutno izboljša zračno vodni režim $\mathrm{v}$ substratu. Ker gre za kamnino, je okoljsko sprejemljiv. Ima nevtralen $\mathrm{pH}$ med 7,0 in 7,5. Zelo lahko se drobi (občutljiv na stiskanje), zato ni primeren za večkratno uporabo. Odlično se meša z ostalimi substrati in je pogosto uporabljen $\mathrm{v}$ vrtnarski pridelavi sadik (Raviv in Lieth, 2008).

Agrogel je brezbarven polimer, ki nase lahko veže več 100-kratno količino vode, zato je primeren za uporabo v več panogah kmetijstva. Je dobro obstojen in sposoben večkratnega navlaženja in sušenja (Raviv in Lieth, 2008).

\subsection{DOLOČITEV VODO ZADRŽEVALNIH LA- STNOSTI ŠOTE}

Za določitev vodo zadrževalnih lastnosti šote smo uporabili tri metode: 1) Richardovo tlačno komoro, 2) neposredno merjenje vodnega potenciala v substratu $\mathrm{s}$ tenziometrom in 3) metodo izhlapevanja.

\subsubsection{Richardova tlačna komora}

Vzorec substrata smo položili $\mathrm{v}$ tlačno posodo sestavljeno iz debelega kovinskega ovoja, v kateri nastavimo želen nadtlak (International ..., 2019). Vzorci so bili položeni na keramično membrano, oziroma ploščo, skozi katero lahko prehaja tekočina. Odvečna tekočina je iztekla iz posode skozi posebno cevko iz nerjavečega jekla. Vzorec vsebuje samo vodo, ki je vezana pri dotičnem tlaku, ko iz cevke ne izteka več voda (Richards, 1941). Vzorce substrata smo zatehtali $\mathrm{v}$ plastične obročke, položene na $\mathrm{z}$ vodo nasičeno keramično ploščo. Plošče smo prelili $\mathrm{z}$ vodo in jih pustili 24 do 48 ur tako, da so bili vzorci substrata popolnoma nasičeni $\mathrm{z}$ vodo. Vzorce smo vstavili v tlačno komoro, nastavili nadtlak in počakali, da se je vzpostavilo ravnovesje med nadtlakom in silo, s katero je voda vezana na substrat. Nadtlaki so bili 0,$02 ; 0,1 ; 0,33 ; 1 ; 3 ; 5$ ter 15 barov. Vzorce smo stehtali, sušili 48 ur na $55^{\circ} \mathrm{C}$ in ponovno stehtali. Iz razlike $\mathrm{v}$ masi vzorcev pred in po sušenju smo izračunali, koliko vode je vzorec zadržal pri določenem nadtlaku.

\subsubsection{Merjenje vodnega potenciala s tenziometrom}

Vodni potencial $(\Psi)$ ali tenzijo šotnega substrata smo merili neposredno s tenziometri (Soilmoisture Equipment, Santa Barbara, US, območje delovanja od 0 do $100 \mathrm{kPa}, \mathrm{z}$ natančnostjo $1 \mathrm{kPa}$ ) (Vaz in sod., 2013; Montesano in sod., 2015) in prikazuje silo vezave vode $\mathrm{v}$ porah substrata, oziroma kakšno silo rastlina potrebuje, da lahko vodo absorbira iz substrata (Schindler in sod., 2015). Večje tenzije pomenijo rastlinam težje dostopno vodo, saj je vezana $z$ večjimi tlaki. Hkrati smo beležili tenzijo s tenziometrom in maso lonca, ki smo ju sušili v pečici na $25{ }^{\circ} \mathrm{C}$ na 12 ur. Iz podatkov smo izrisali krivuljo odvisnosti vsebnosti vode od tenzije.

\subsubsection{Metoda izhlapevanja}

Vodo zadrževalne lastnosti substrata smo določili z metodo izhlapevanja (Schindler in sod., 2010, Bezerra-Coelho in sod., 2018). Cilindre iz nerjavečega jekla (5 $\mathrm{cm}$ visoki in $8 \mathrm{~cm}$ široki) smo napolnili $\mathrm{z}$ vzorci šote $\mathrm{z}$ gostoto $1,05 \mathrm{~g} \mathrm{~cm}^{-3}$. Vzorce smo nasičili $\mathrm{z}$ vodo tako, da smo jih postavili na $\mathrm{z}$ vodo navlaženo posodo. $\mathrm{V}$ vzorce smo vstavili tenziometre $\mathrm{v}$ središče vzorca. Površina šote je bila izpostavljena naravnemu izhlapevanju. Spremljali smo maso in tenzijo vsakih 10 minut, nekaj zaporednih dni. Hidravlični gradient je bil izračunan na podlagi tenzij izmerjenih med meritvami. Posamezne točke na krivulji vodo zadrževalnih lastnosti so bile izračunane na podlagi izgube vode na volumen vzorca (Schindler in sod., 2015). Po tej metodi nenasičeno prevodnost substrata določimo $\mathrm{z}$ merjenjem vodne tenzije s pomočjo majhnih tenziometrov in programa Hyprop fit (Schindler in sod. 2010), ter uporabo pretvorbene funkcije tal (pedotransfer function). Model (HYPROP-FIT software [Meter/UMS 
GmbH, Germany]), po katerem smo izračunali krivuljo vodo zadrževalnih lastnosti, je bil model po Brooks in Corey (1964).

\subsection{VODOODBOJNOST}

Za preizkus vodoodbojnostnih lastnosti šotnega substrata smo uporabili neuporabljen šotni substrat in metodo WDPT (Water Drop Penetration Time) (Letey, 1969; Leelamanie in sod., 2008; Saldanha Vogelmann in sod., 2015). Metoda WDPT je enostavna, saj se jo lahko izvede na terenu ali v laboratoriju in se jo lahko izvede na porušenih ali neporušenih vzorcih. Prednost metode je v tem, da vzorcev ni potrebno predhodno obdelati, s čimer bi spremenili lastnosti površine vzorca (Ritsema in Dekker, 1994). Na vzorec substrata ali tal kanemo tri kapljice bi-destilirane vode ter merimo čas vpijanja s štoparico. S časom se kontaktni kot med substratom in kapljico zmanjša, kar omogoča kapljici prodor v substrat (Greiffenhagen in sod., 2006). Meritve smo izvajali med sušenjem na vsakih 7 ur. Substrat se je sušil v pečici na $50^{\circ} \mathrm{C}$. Po sušenju smo substrat ohladili v eksikatorju in stehtali maso substrata. Opravili smo pet ponovitev. Količino vode v substratu smo izračunali kot volumske odstotke vode.

\subsection{STATISTIČNA OBDELAVA PODATKOV}

Povprečja in standardne napake so bili izračunani s pomočjo programa R (Team R.D.C., 2008). Kjer je enosmerna analiza variance (ANOVA) potrdila statistično značilne razlike, smo naredili Tukey-test. Stopnja značilnosti je bila $\alpha \leq 0,05$.

\section{REZULTATI Z DISKUSIJO}

\subsection{MASA SUHEGA IN NEUPORABLJENEGA SUB-}

\section{STRATA PRED IN PO UPORABI}

V Preglednici 1 so podatki za mase neuporabljenega in uporabljenega substrata ob konstantnem sušenju pri $25{ }^{\circ} \mathrm{C}$. Za suhi substrat so podatki iz zaključka poskusa. Neuporabljen šotni substrat ima v povprečju maso 341,9 g. Pri kombinaciji s neuporabljenim substratom imata najmanjšo maso po nasičenju mešanici šota in $2 \mathrm{~cm}$ disk kamene volne in mešanica šote in agrogela (303,7 $\mathrm{g}$ in 308 $\mathrm{g}$ in), največjo maso pa šota $\mathrm{z}$ dodanimi $20 \%$ vol kosmi kamene volne $(372,7 \mathrm{~g})$. Največja razlika med maso neuporabljenega vlažnega substrata in suhega substrata je pri šoti z 20 vol \% kosmov in 20 vol \% vermikulita (196,5 g in $173,5 \mathrm{~g})$. Najmanjšo maso doseže suha mešanica šote in 2 cm diska kamene volne (135,8 g).

Pri uporabljenem substratu je največ vode zadržala kombinacija substrata s šoto in kosmi kamene volne (307 g), najmanj pa šota $\mathrm{z}$ agrogelom $(286,1 \mathrm{~g})$. Dva do trikratna razlika je prisotna pri masi neuporabljenega in uporabljenega suhega substrata. Med uporabljenimi posušenimi substrati ima najmanjšo maso substrat $\mathrm{z}$ agrogelom in 2 $\mathrm{cm}$ diskom kamene volne (58 g in 58,5 g). Največje razlike med maso uporabljenega vlažnega in suhega substrata je pri $2 \mathrm{~cm}$ disku $(235,9 \mathrm{~g})$ in kosmih $(240,8 \mathrm{~g})$. Razlike v masi med neuporabljenim substratom (suhim) in uporabljenim substratom (suhim) so posledica razgradnje šote med pridelavo rastlin. Zmanjšana masa uporabljenega substrata je posledica zmanjšane poroznosti, predvsem na račun zapolnitve por s koreninami in sesedanja šote ter kamene volne (Raviv in Lieth, 2008).

\subsection{IZGUBA VODE}

Izgube vode $\mathrm{v}$ šoti ter mešanicah šote $\mathrm{z}$ dodatki so predstavljeni na Slikah 1A in 1B. Na Sliki 1A so podatki o izhlapevanju vode iz neuporabljenih substratov. Izhodiščno se v neuporabljenem substratu zadrži več vode kot $\mathrm{v}$ ponovno uporabljenem, saj neuporabljen substrat pri

Preglednica 1: Povprečne mase (s standardno napako) neuporabljenega in uporabljenega substrata po nasičenju (po zaključku sušenja na $\left.25^{\circ} \mathrm{C}\right)$. Črke od a do d predstavljajo statistično značilne razlike med obravnavanji.

Table 1: Mass (average + standard error) of unused and used substrate after saturation (after drying at $25^{\circ} \mathrm{C}$ ). Letters a to $\mathrm{d}$ represent statistically significant differences among treatments.

\begin{tabular}{lllll} 
Substrat & Neuporabljen & & Uporabljen & \\
& Vlažen $(\mathrm{g})$ & Suh $(\mathrm{g})$ & Vlažen $(\mathrm{g})$ & Suh $(\mathrm{g})$ \\
Šota & Kontrola) & $180,9 \pm 2,3 \mathrm{a}$ & $289,4 \pm 3,1 \mathrm{~b}$ & $62,4 \pm 0,9 \mathrm{bc}$ \\
Šota + 2 cm disk kamene volne & $341,9 \pm 6,5 \mathrm{ab}$ & $135,8 \pm 3,9 \mathrm{c}$ & $294,4 \pm 5,8 \mathrm{ab}$ & $58,5 \pm 0,8 \mathrm{~cd}$ \\
Šota + kosmi kamene volne 20 vol \% & $372,7 \pm 1,92 \mathrm{a}$ & $176,2 \pm 1,4 \mathrm{a}$ & $307,0 \pm 3,8 \mathrm{a}$ & $66,2 \pm 1,0 \mathrm{ab}$ \\
Šota + vermikulit 20 vol \% & $340,9 \pm 7,4 \mathrm{ab}$ & $167,3 \pm 4,7 \mathrm{ab}$ & $294,1 \pm 3,5 \mathrm{ab}$ & $68,1 \pm 1,3 \mathrm{a}$ \\
Šota + agrogel & $308,0 \pm 7,5 \mathrm{~b}$ & $152,7 \pm 10,4 \mathrm{bc}$ & $286,1 \pm 1,2 \mathrm{~b}$ & $58,0 \pm 0,4 \mathrm{~d}$ \\
\hline
\end{tabular}


kontroli zadrži $16,2 \%$, pri $2 \mathrm{~cm}$ disku 3,4 \%, pri kosmih $18,4 \%$, pri vermikulitu $12,9 \%$ in agrogelu $7,3 \%$ več vode kot pri uporabljenem substratu $\mathrm{v}$ kombinaciji s temi dodatki. Največ vode je zadržala mešanica $80 \%$ neuporabljene šote in $20 \%$ kosmov iz kamene volne (358 ml), najmanj pa šota $\mathrm{z}$ dodanim agrogelom $(302 \mathrm{ml})$ in $2 \mathrm{~cm}$ diskom kamene volne $(298 \mathrm{ml})$. Kamena volna izboljša zračnost substratnih mešanic in poveča sposobnost zadrževanja vode v substratu. Vermikulit izboljša poroznost substrata in njegovo sposobnost zadrževanja vode (Raviv in Lieth, 2008; Beyl in Trigiano, 2015).

Izgube vode med neuporabljenimi substrati so enakomerne. Uporabljen substrat, ki je bil ponovno navlažen, zadrži manj vode kot neuporabljen substrat. Največ vode zadrži šotni substrat s kosmi kamene volne (298 ml). Najmanj vode lahko zadrži substrat $\mathrm{z}$ dodanim agrogelom in klasičen šotni substrat brez dodatkov (oba $280 \mathrm{ml}$ ). Zanimivo se obnaša šotni substrat z $2 \mathrm{~cm}$ diskom kamene volne, saj v začetku zadržuje vodo podobno kot ostale mešanice, po treh dneh pa se je vsebnost vode strmo zmanjšala, do najnižje točke med vsemi substrati. Največja razhajanja med neuporabljenimi in že uporabljenimi substrati se pojavijo, ko izhlapi ali odteče $24 \%$ vode iz substrata, štiri dni po začetku izsuševanja substrata. Razlike v sposobnosti zadrževanja vode so bolj izrazite pri že uporabljenih substratih, saj dodatki pridejo bolj do izraza (Diara et al., 2012). Iz podatkov lahko razberemo, da je priporočljivo namakanje sadik v rastlinjakih v več manjših obrokih in rednih intervalih (Ismail in sod., 2007; Raviv in Blom, 2001). Če substrate pustimo preveč dolgo nenamakane, se ti izsušijo in izgubijo del sposobnosti zadrževanja vode. Dodajanje kamene volne šoti izboljša poroznost mešanice in s tem poveča kapaciteto za vodo (Kim in Jeong, 2003). Podobne rezultate smo dobili tudi $\mathrm{v}$ naši raziskavi, kjer ima šota $\mathrm{z}$ dodatkom kosmov kamene volne boljšo sposobnost zadrževanja vode kot šota brez dodane kamene volne.

Povprečna dnevna izguba vode v substratih je predstavljena v preglednici 2. Šotni substrat (kontrola) dnevno izgubi 13,08 g mase (vode) pri neuporabljenem substratu. Uporabljen šotni substrat dnevno izgubi 11,67 ml vode. Največje dnevne izgube vode ima mešanica šote in kameno volnatih kosmov (14,95 ml/dan), najmanjše pa šota na $2 \mathrm{~cm}$ disku kamene volne $(12,30 \mathrm{ml} / \mathrm{dan})$. Kamena volna ima rahlo vezano vodo, ki lahko hitro izhlapi, zato je šota služila kot prepreka pred izhlapevanjem vode, posledično je imela ta kombinacija najmanjše izgube vode.

Med uporabljenimi substrati največ vode izgubi šota na $2 \mathrm{~cm}$ disku kamene volne $(12,73 \mathrm{ml} /$ dan $)$, najmanj pa šota $\mathrm{z}$ vermikulitom $(10,89 \mathrm{ml} /$ dan $)$. Pri vseh substratih je uporabljen substrat dnevno izgubil manj vode kot neuporabljen substrat, razen pri šoti na $2 \mathrm{~cm}$ disku kamene volne, kjer je uporabljen substrat dnevno izgubil več vode $(0,44 \mathrm{ml} / \mathrm{dan})$. Kljub manjši dnevni izgubi vode uporabljenega substrata je imel uporabljen substrat slabše vodo zadrževalne lastnosti, saj je vseh pet substratov zadržalo pod $300 \mathrm{ml}$ vode, medtem ko so neuporabljeni

A

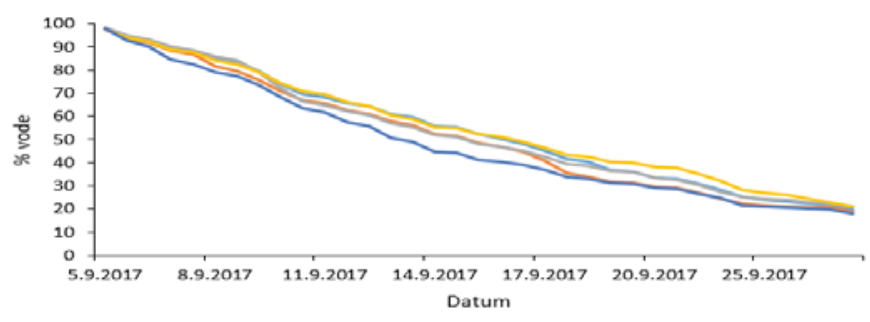

B

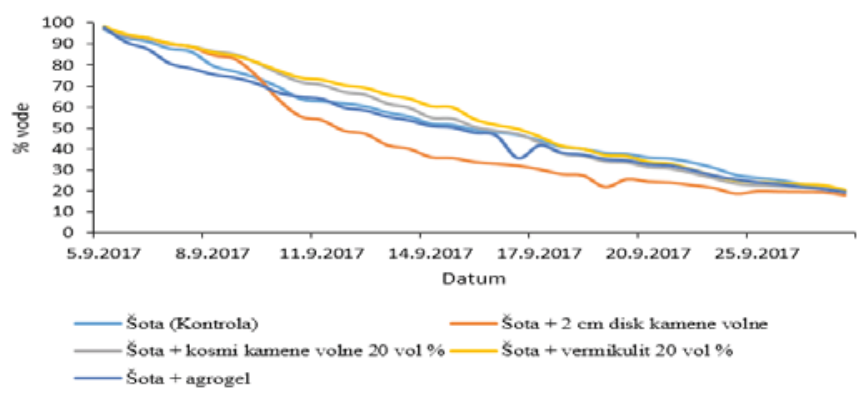

Slika 1: Izgube vode neuporabljenega šotnega substrata in mešanic $(A)$ in izgube vode uporabljenega šotnega substrata in mešanic (B).

Figure 1: Water losses of unused peat substrate and mixtures (A) and water losses of used peat substrate and mixtures (B) 
Preglednica 2: Povprečna izguba (s standardno napako) vode v $\mathrm{ml}$ na dan pri različnih mešanicah šotnih substratov. Črke od a do c predstavljajo statistično značilne razlike med obravnavanji.

Table 2: Average water loss (with standard error) in $\mathrm{ml}$ per day in different mixtures of peat substrates. Letters a to $\mathrm{c}$ represent statistical significant differences among treatments.

\begin{tabular}{lll}
\hline Substrat & Neuporabljen (ml/dan) & Uporabljen (ml/dan) \\
\hline Šota (kontrola) & $13,08 \pm 0,76 \mathrm{bc}$ & $11,67 \pm 0,06 \mathrm{ab}$ \\
Šota + 2 cm disk kamene volne & $12,30 \pm 0,70 \mathrm{c}$ & $12,73 \pm 0,63 \mathrm{a}$ \\
Šota + kosmi kamene volne 20 vol \% & $14,95 \pm 0,19 \mathrm{a}$ & $11,89 \pm 0,22 \mathrm{ab}$ \\
Šota + vermikulit 20 vol \% & $13,14 \pm 0,79 \mathrm{bc}$ & $10,89 \pm 0,08 \mathrm{~b}$ \\
Šota + agrogel & $13,36 \pm 0,81 \mathrm{ab}$ & $12,00 \pm 0,40 \mathrm{ab}$ \\
\hline
\end{tabular}

substrati zadržali nad $300 \mathrm{ml}$ vode. Največja razlika pri izgubi vode je bila pri mešanici šote in kameno volnatih kosmov $(3,06 \mathrm{ml} / \mathrm{dan})$ med neuporabljenim in uporabljenim substratom. Za najboljšo mešanico se je izkazala kombinacija neuporabljene šote $\mathrm{z}$ dodanimi kosmi kamene volne, ki je izkazala največjo sposobnost zadrževanja vode. Kljub največji dnevni izgubi vode od vseh obravnavanih mešanic v enem tednu v povprečju še vedno ohrani največjo količino vode $\mathrm{v}$ primerjavi $\mathrm{z}$ drugimi substrati. Najslabša mešanica za daljše obdobje nenamakanja je mešanica šote in agrogela, saj ima najmanjšo sposobnost zadrževanja vode ter drugo največjo dnevno izgubo vode. Substratne mešanice s kameno volno imajo večje izgube vode predvsem na račun slabo vezane vode v kameni volni (Donnersa in sod., 2019). Zaradi velike poroznosti vermikulita in s tem dobre kapacitete za vodo, katera je dobro vezana, dnevne izgube zaradi sušenja niso tako očitne, kot pri drugih materialih (Raviv in Lieth, 2008). Podobno se je izkazalo v naši raziskavi, kjer je mešanica šote in vermikulita imela najmanjše dnevne izgube vode.

\subsection{VODO ZADRŽEVALNE LASTNOSTI ŠOTE}

$\mathrm{V}$ analizi smo preverili vodo zadrževalne lastnosti s tremi metodami - dvema laboratorijskima (Richardova tlačna komora, 3.3.1. in metoda izhlapevanja, 3.3.3.) in metodo, ki jo lahko uporabljamo na terenu oziroma rastlinjaku (metoda s tenziometrom, 3.3.2). Prednost tega pristopa je v širini intervala, ki smo ga zajeli, saj smo analizirali vodozadrževalne lastnosti tekom celotnega intervala rastlinam dostopne vode (Richardova tlačna komora, 3.3.1). Hkrati smo upoštevali strukturo, ki se vzpostavi v šotnem substratu, ko ga uporabimo za gojenje $\mathrm{v}$ loncih (metoda s tenziometrom, 3.3.2 in metoda izhlapevanja, 3.3.3.). Česar v poskusu nismo preverili, so mikrobiološke lastnosti substratov, katere $\mathrm{v}$ tleh lahko vplivajo na oblikovanje koloidnih delcev in s

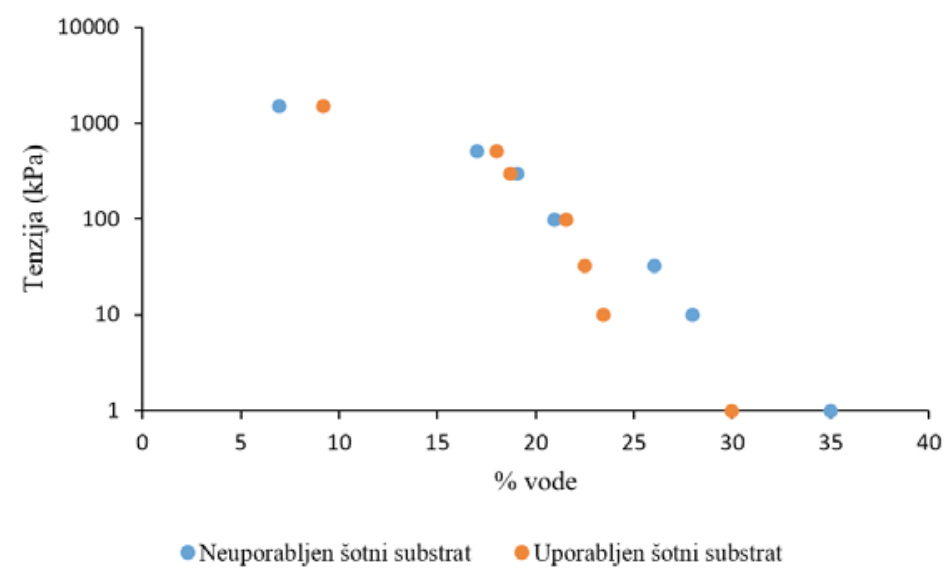

Slika 2: Razmerje med vsebnostjo vode v šotnem substratu (\%), in silo vezave $(\mathrm{kPa})$, izmerjeno $\mathrm{z}$ Richardovo tlačno membrano. Vrednosti na y osi so logaritmirane.

Figure 2: Peat water content $(\%)$ and peat water tension $(\mathrm{kPa})$, measured with Richard's pressure plate. The values on the y axis are in logarithmic scale. 
tem vplivajo na sposobnost zadrževanja vode (Tecon in Or, 2017).

\subsubsection{Richardova tlačna komora}

Neuporabljen šotni substrat ima večjo kapaciteto za vodo oziroma večji \% vode kot uporabljen substrat (Slika 2). Neuporabljen šotni substrat zadrži $5 \%$ več vode pri 1 $\mathrm{kPa}$ kot uporabljen šotni substrat. Pri obeh šotnih substratih se delež vode enakomerno zmanjšuje do $100 \mathrm{kPa}$ oziroma enega bara. Med $100 \mathrm{kPa}$ in $300 \mathrm{kPa}$ oziroma med 1 in 3 bari je \% vode enak pri obeh substratih. Volumen vode se zmanjšuje pri obeh substratih enako. Pri vrednostih nad $500 \mathrm{kPa}$ uporabljen šotni substrat zadrži večji delež vode kot neuporabljen substrat (za 2,25 \% pri $1500 \mathrm{kPa}$ oziroma 15 barih). Med uporabljenim in neuporabljenim šotnim substratom so očitne razlike v količini dostopne vode, uporabljeni šotni substrat ima ožji interval rastlinam dostopne vode (med območjem poljske kapacitete in točko venenja). $V$ uporabljenem šotnem substratu se zmanjša poroznost, kar je lahko posledica starih korenin (Urrestarazu in sod., 2008).

\subsubsection{Merjenje vodnega potenciala s tenziometrom}

Pri uporabljenem šotnem substratu smo s tenziometrom izmerili večje tenzije ob postopnem sušenju substrata kot pri neuporabljenem substrat (Slika 3). Med neuporabljenim in uporabljenim šotnim substratom se razlike večajo, ko iz substrata izhlapi, odteče ali porabi med 30 in $35 \%$ vode. Pri našem poskusu je bilo to med 500 in $600 \mathrm{ml}$ vode. Bolj, ko se šota suši (večja izguba vode), bolj je vidna razlika med uporabljenim in neuporabljenim substratom.

Pri uporabljenem šotnem substratu je krivulja izgube vode manj strma kot pri neuporabljenem šotnem substratu, kjer krivulja po določeni izgubi vode začne hitro naraščati. Pri tenzijah med 0 in $5 \mathrm{kPa}$ je vsebnost vode $v$ obeh šotnih substratih podobna. Uporabljen šotni substrat zadrži nekoliko več vode kot neuporabljen šotni substrat. Razlike se pojavijo pri tenzijah nad $10 \mathrm{kPa}$. Za rastlino to pomeni, da je voda lahko dostopna do neke točke, nato pa se začne njena dostopnost hitro zmanjševati, kar lahko povzroči stres za rastline in njihov propad. $\mathrm{V}$ praksi to pomeni, da morajo pridelovalci količino vode vzdrževati nad to točko, kar je v primeru analiziranega substrata 10k. Namakanje $\mathrm{v}$ rastlinski pridelavi je priporočljivo v območju poljske kapacitete, ki je pri šoti pri tenziji med 10 in $30 \mathrm{kPa}$ (Raviv in Lieth, 1979). V tem območju tenzije se pojavijo velike razlike med uporabljenim in neuporabljenim šotnim substratom, saj neuporabljeni šotni substrat zadrži več vode pri manjši tenziji kot šotni uporabljen substrat.

\subsubsection{Metoda izhlapevanja}

Pri šotnih substratih je območje poljske kapacitete (PK) med 10 in $33 \mathrm{kPa}$ oziroma med 25 in $32 \%$. Optimalno območje namakanja za rastline je med 25 in $35 \%$ (Handrek in Black, 2002). Točka venenja (TV) za šotni substrat je med 300 in $1500 \mathrm{kPa}$ oziroma med 18 in $15 \%$. Točka poljske kapacitete je največja količina vode, ki jo tla lahko zadržijo, točka venenja pa je količina vode $\mathrm{v}$ tleh, pri kateri rastline trajno uvenijo in si ne opomorejo, četudi jih zalijemo (Pintar, 2006).

Voda, vezana z manjšo silo od poljske kapacitete (za

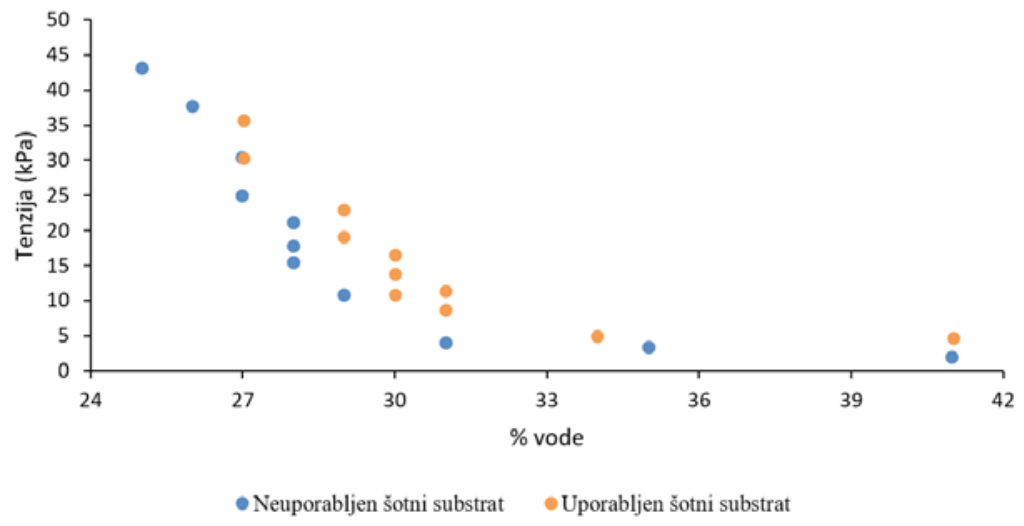

Slika 3: Razmerje med vsebnostjo vode v šotnem substratu (\%) in silo vezave $(\mathrm{kPa})$, izmerjeno s tenziometrom. Figure 3: Peat water content $(\%)$ and peat water tension $(\mathrm{kPa})$, measured with tensiometer. 
mineralna tla je to med 10 in $33 \mathrm{kPa}$ ), prehitro odteče iz substrata in rastlini ni dostopna. Voda, ki je vezana s silo večjo od točke venenja $(1500 \mathrm{kPa})$, je prav tako nedostopna rastlini (Pintar in Zupanc, 2017). Iz Slike 4 lahko razberemo, da je voda $\mathrm{v}$ šotnem substratu dobro razpoložljiva do meje $200 \mathrm{kPa}$, nato hitro postane nedostopna za rastlino, kar vodi v venenje listov zaradi padca turgorja v celicah. Daljše obdobje suše, kjer je dostopnost vode težja za rastlino ( > $1500 \mathrm{kPa}$ ), lahko pripelje do propada celotne rastline. Pri šotnih substratih je prehod iz območja poljske kapacitete substrata do točke venenja hiter, razlika je 7 do $10 \%$, kar lahko pridelovalcu povzroči preglavice, če namakanje ni dosledno. V rastlinjakih se lahko zgodi prehod še hitreje, saj so temperature $\mathrm{v}$ rastlinjakih poleti lahko mnogo višje. Al-Mahdouri in sod. (2013) poročajo o povprečnih temperaturah zraka med 83 in $93{ }^{\circ} \mathrm{C}$ glede na različne kritine ter temperature tal med $104,8^{\circ} \mathrm{C}$ in 119,5 ${ }^{\circ} \mathrm{C}$, če se rastlinjakov ustrezno ne zrači. Z ustreznim namakanjem oziroma režimom namakanja lahko šotni substrat vzdržujemo v območju poljske kapacitete. Priporočljivo je namakanje v več manjših obrokih, saj tako lažje vzdržujemo konstanto količino vode v substratu, saj je voda v območju poljske kapacitete najlažje dostopna za rastlino (Zamljen in sod., 2020). Če namakamo v večjih količinah in manj pogosto, presežemo vodo zadrževalne sposobnosti substrata $\mathrm{v}$ loncu in voda odteče iz substrata. Voda, ki odteče, za rastlino ni več dostopna razen, če jo zadržimo s pomočjo podstavkov v primeru gojenja rastlin $\mathrm{v}$ posodah. Naši rezultati so pokazali, da lahko z mešanjem šote z drugimi tipi substratov občutno izboljšamo vodo zadrževalne sposobnosti šote.

\subsection{VODOODBOJNOST}

$\mathrm{Na}$ Sliki 5 so podatki za čas vpijanja kapljice neuporabljenega šotnega substrata in rabljenega šotnega substrata. Šotni substrat smo sušili do konstantne mase, tri dni, dokler ni bil popolnoma suh. Hkrati smo na šotni substrat dodajali kapljice vode in spremljali, koliko časa potrebujejo, da se vpijejo. Masa šotnega substrata se s časom zmanjšuje na račun izgube vode. Bolj ko je šotni substrat suh, težje vpije vodo oziroma kapljice vode (Raviv in Lieth, 2008). Popolnoma navlažen šotni substrat nima vodoodbojnih lastnosti (čas vpijanja kapljice je nič sekund). Pri osuševanju popolnoma navlaženega neuporabljenega substrata se je pri $42 \%$ čas vpijanja kapljice podaljšal na eno sekundo, pri uporabljenem šotni substratu se je čas vpijanja kapljice podaljšal že pri $59 \%$. Ko količina vode v šoti doseže kritično vrednost, postane šota hidrofobna, kar pomeni težji sprejem vode in ponovno navlažitev šotni substrata (Perdana in sod., 2018). Podobno se je izkazalo tudi v našem primeru. Čas vpijanja kapljice v šotni substrat začne naraščati, ko je v neuporabljenem šotni substratu med $35 \%$ in $40 \%$ vode. Za vsakih 10 do $20 \mathrm{ml}$ izhlapene vode iz šotnega substrata se čas vpijanja kapljice poveča med 2 in 3 sekunde. Popolnoma suh šotni substrat potrebuje 15 sekund, da vpije kapljico, kar v primerjavi s peščenimi tlemi ni veliko (Oostindie in sod., 2013; Dekker in sod., 2001).

Vodoodbojnost pri rabljenem šotnem substratu začne naraščati pri $59 \%$. Z zmanjševanjem vsebnosti vode rabljen šotni substrat pridobiva vse večje vodoodbojnostne lastnosti, ki se kažejo kot eksponentna rast. Pri 30 \% navlaženosti šotnega substrata je čas vpijanja

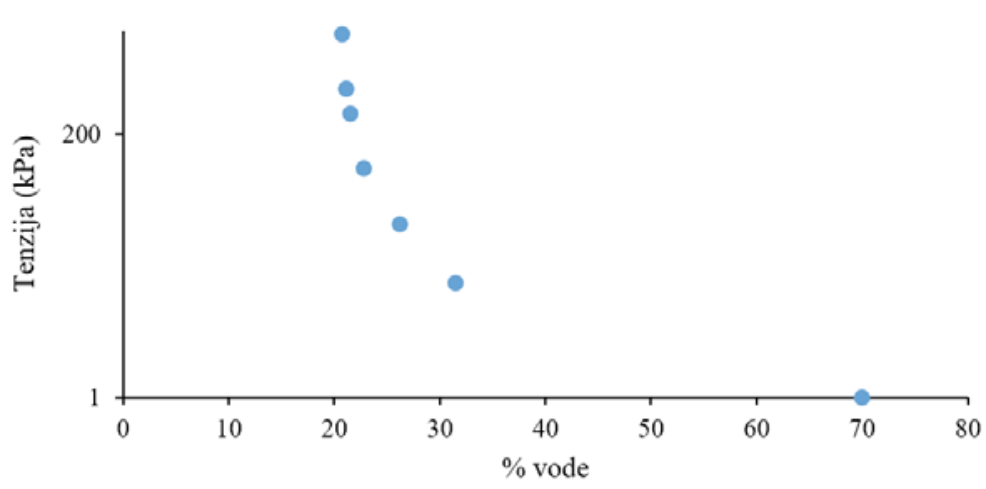

- Šotni substrat

Slika 4: Razmerje med vsebnostjo vode v šotnem substratu (\%) in silo vezave (kPa), izmerjeno z metodo izhlapevanja. Vrednosti na y osi so logaritmirane.

Figure 4: Peat water content $(\%)$ and peat water tension $(\mathrm{kPa})$, measured with evaporation method. The values on the $y$ axis are in logarithmic scale. 

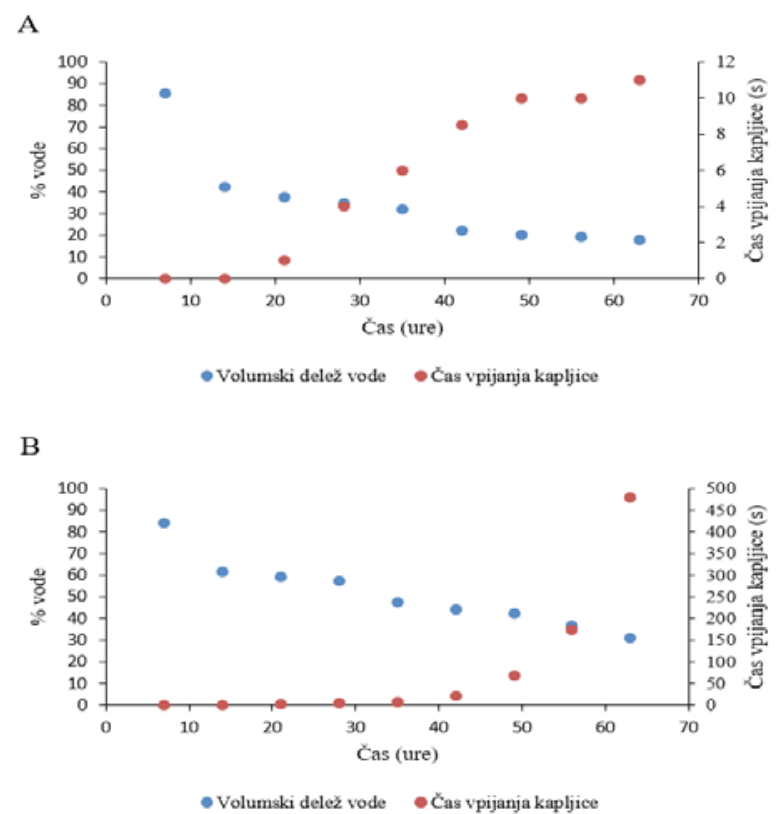

Slika 5: Čas vpijanja vodne kapljice (s) glede na količino vode (\%) pri neuporabljenem (A) in uporabljenem (B) šotnem substratu tekom meritev (ure).

Figure 5: Water drop penetration time (s) and water content (\%) for unused (A) and used (B) peat substrate during the experiment (hrs).

kapljice 480 sekund oziroma 8 minut. Glavni razlog za povečanje hidrofobnih lastnosti rabljenega šotnega substrata je $\mathrm{v}$ povečanem deležu organske mase predvsem zaradi ostankov korenin (Wu in sod., 2020). Pri mineralnih tleh (glinenih tleh) se vodoodbojnostne lastnosti začnejo kazati, ko se vsebnost vode zmanjša pod $41 \%$, med tem ko se pri močno organskih tleh vodoodbojnostne lastnosti kažejo tudi pri popolnoma nasičenih tleh (Rasa in sod., 2007). Razmerje med časom vpijanja kapljice in maso šotnega substrata je obratno sorazmerno. Bolj kot je šotni substrat suh, daljši je čas vpijanja kapljice in obratno, bolj kot je vlažen šotni substrat, krajši je čas vpijanja kapljice. Kapljico izsušena tla lahko vpijejo $\mathrm{v}$ manj kot 10 minutah ali pa za vpijanje potrebujejo več kot 6 ur (Oostindie in sod., 2013).

\section{SKLEPI}

Šota je izjemno uporaben substrat za gojenje vrtnin. Pridelovalec mora rastline dosledno namakati ter vzdrževati konstantno količino vode $\mathrm{v}$ substratu. Prehod iz poljske kapacitete (50 do $70 \%$ vode v substratu) v točko venenja (7 do $10 \%$ vode v substratu) je zelo hiter in se lahko zgodi v nekaj urah. Šota ni primerna za daljše intervale namakanja, saj se v primeru izsušitve njene lastnosti spremenijo, pojavi se vodoodbojnost, substrat se skrči, zmanjša se poroznost. Suh šotni substrat je težje ponovno navlažiti. Prav tako uporabljen šotni substrat ne zadrži ob nasičenju enake količine vode kot neuporabljen substrat. Ponovna uporaba šotnega substrata ni priporočljiva, ker ima manjšo kapaciteto za vodo in hitreje pridobi vodoodbojne lastnosti.

Glede na sposobnost zadrževanja vode se je med najboljšimi mešanicami izkazala mešanica šote in $20 \%$ kosmov kamene volne, saj zadrži največ vode. Najslabše se je med mešanicami substratov odrezala šota $z$ diskom kamene volne in šota $\mathrm{z}$ dodanim agrogelom. Že rabljen substrat zadrži manj vode kot neuporabljeni substrat ne glede na mešanico. Šota na disku kamene volne izgubi veliko vode po treh dneh.

Šotni substrat je potrebno $v$ rastlinski pridelavi namakati redno in $\mathrm{v}$ več manjših obrokih, da preprečimo izsušitev in vzdržujemo območje poljske kapacitete. Med preizkušenimi mešanicami bi bila za pridelovalce zanimiva uporaba 80 \% šote in 20 \% kosmov kamene volne, saj zadrži največ vode med vsemi preizkušenimi mešanicami. Ponovna uporaba že uporabljenih substratov ni priporočljiva, predvsem zaradi slabših vodo zadrževalnih lastnosti ter fitosanitarne vprašljivosti.

Raziskava dokazuje, da je šotni substrat zelo primeren za gojenje vrtnin ob ustreznem namakanju. Z različnimi dodatki lahko izboljšamo vodo zadrževalne lastnosti šotnega substrata, s čimer lahko zmanjšamo po- 
rabo vode pri namakanju ter s tem zmanjšamo pritisk na naravne vire. $\mathrm{V}$ prihodnje želimo raziskavo nadgraditi s preizkušanjem mešanic $\mathrm{v}$ različnih razmerjih in kombinacijah dodatkov.

\section{$5 \quad$ VIRI}

Al-Mahdouri, A., Baneshi, M., Gonome, H., Okajima, J., Maruyama, S. (2013). Evaluation of optical properties and thermal performances of different greenhouse covering materials. Solar Energy, 96, 21-32. https://doi.org/10.1016/j. solener.2013.06.029

Beyl, A. C., Trigiano, N. R. (2015). Plant Propagation Concepts and Laboratory Exercises. Taylor \& Francis Group, LLC. 480 str. https://doi.org/10.1201/b17340

Bezerra-Coelho, R. C., Zhuang, L., Barbosa, C. M., Soto, A. M., Genuchten, M. T. (2018). Further tests of the HYPROP evaporation method for estimating the unsaturated soil hydraulic properties. Journal of Hydrology and Hydromechanics, 66(2), 9 str. https://doi.org/10.1515/johh-2017-0046

Brooks, R. H., Corey, A. T. (1964). Hydraulic properties of porous media. Fort Collins, Colorado ST. Univ.: 24 str.

Dekker, W. L., Doerr, H. S., Oostindie, K., Ziogas, K. A., Ritsema, J. C. (2001). Water Repellency and Critical Soil Water Content in a Dune Sand. Soil Science Society of America Journal, 65, 1667-1674. https://doi.org/10.2136/ sssaj2001.1667

Diara, C., Incrocci, L., Pardossi, A., Minuto, A. (2012). Reusing greenhouse growing media. Acta horticulturae, 927, 793-800. https://doi.org/10.17660/ActaHortic.2012.927.98

Faul, F., Gabriel, M., Roßkopf, N., Zeitz, J., Huyssteen, W. C., Pretorius, L. M., Grundling, P. (2016). Physical and hydrological properties of peatland substrates from different hydrogenetic wetland types on the Maputaland Coastal Plain, South Africa. South African Journal of Plant and Soil, 33(4), 265-278. https://doi.org/10.1080/02571862.2016.1141334

Giancarlo, F. (2015). Growing Substrates Alternative to Peat for Ornamental Plants. InTech Publication: 47-67.

Greiffenhagen, A., Wessolek, G., Facklam, M., Renger, M., Stoffregen, H. (2006). Hydraulic functions and water repellency of forest floor horizons on sandy soils. Geoderma, 132, 182195. https://doi.org/10.1016/j.geoderma.2005.05.006

Grover, S. P. P., J. A. Baldock (2013). The link between peat hydrology and decomposition: Beyond von Post. Journal of Hydrology, 479, 130-138. https://doi.org/10.1016/j.jhydrol.2012.11.049

Handrek, K., Black, N. (2002). Growing media for ornamental plants and turf. Sidney: University of New South Wales Press: 542 str.

Humko. (2020). Neuhaus humin substrat N3 70lit. Pridobljeno s https://www.humko-shop.si/index.php?route=product/ product\&product_id $=10496$ (17. mar. 2020)

International Organization for Standardization. (2019). Soil quality-Determination of the water-retention characteristicLaboratory methods (ISO Standard No. 11274) Pridobljeno s https://www.iso.org/standard/68256.html (16. mar. 2020)

Ismail, M. S., Ozawa, K., Khondaker, A. N. (2007). Effect of ir- rigation frequency and timing on tomato yield, soil water dynamics and water use efficiency under drip irrigation. Eleventh International Water Technology Conference, 69-84.

Kim, G. H., Jeong B. R. (2003). Hydroponic culture of a pot plant Ficus benjamina 'King' using mixtures of used rockwool slab particles and chestnut woodchips. Journal of Korean Society of Horticultural Science, 44, 251-254.

Kipp, J. A., Wever, G., de Kreij, C. (2000). International Substrate Manual. The Netherlands: Elsevier. 94 str.

Leelamanie, D. A. L., Karube, J., Yoshida, A. (2008). Characterizing water repellency indices: Contact angle and water drop penetration time of hydrophobized sand. Soil Science \& Plant Nutrition, 54(2), 179-187. https://doi.org/10.1111/ j.1747-0765.2007.00232.x

Letey, J. (1969). Measurement of contact angle, water drop penetration time and critical surface tension. In: DeBano, L. F., Letey, J. (Eds.), Water Repellent Soils. Proceedings Symposium on Water Repellent Soils. University of California, Riverside: 43-47.

Montesano, F. F., Serio, F., Mininni, C., Signore, A., Parente, A., Santamaria, P. (2015). Tensiometer Based Irrigation Management of Subirrigated Soilless Tomato: Effects of Substrate Matric Potential Controlon Crop Performance. Frontiers in Plant Science, 6, 1-11. https://doi.org/10.3389/ fpls.2015.01150

Oostindie, K., Dekker, W. L., Wesseling, G. J., Ritsema, J. C., Geissen, V. (2013). Development of actual water repellency in a grass-covered dune sand during a dehydration experiment. Geoderma, 204-205, 23-30. https://doi.org/10.1016/j. geoderma.2013.04.006

Perdana, L. R., Ratnasari, N. G., Ramadhan, M. L., Palamba, P., Nasruddin, N., Nugroho, Y. S. (2018). Hydrophilic and hydrophobic characteristics of dry peat. IOP Conference Series Earth and Environmental Science, 105(1), 7 str. https://doi. org/10.1088/1755-1315/105/1/012083

Pintar, M. (2006). Osnove namakanja s poudarkom na vrtninah in sadnih vrstah $v$ zahodni, osrednji in južni Sloveniji. Ljubljana, Ministrstvo za kmetijstvo, gozdarstvo in prehrano RS: 55 str.

Pintar, M., Zupanc, V. (2017). Deficitno namakanje v poljedelstvu in zelenjadarstvu - izzivi in perspektive. V: Novi izzivi v agronomiji 2017: zbornik simpozija, Laško, 26.-27. jan. 2017. Ljubljana, Slovensko agronomsko društvo, 272-276.

Rasa, K., Horn, R., Räty, M., Yli-Halla, M., Pietola, L. (2007). Water repellency of clay, sand and organic soils in Finland. Agricultural and Food Science, 16, 267-277. https://doi. org/10.2137/145960607783328218

Raviv, M., Lieth, J. H. (1979). Yield response to water. FAO irrigation and drainage paper 33.

Rome: FAO: 193 str.

Raviv, M., Blom, J. T. (2001). The effect of water availability and quality on photosynthesis and productivity of soillessgrown cut roses. Scientia Horticulturae, 88(4), 257-276. https://doi.org/10.1016/S0304-4238(00)00239-9

Raviv, M., Lieth, J. H. (2008). Soilless Culture: Theory and Practice. Elsevier. 587 str.

Richards, L. A. (1941). A pressure-membrane extraction apparatus for soil solution. Soil Science, 51(5), 377-386. https:// doi.org/10.1097/00010694-194105000-00005 
Ritsema, J. C., Dekker, W. L. (1994). How water moves in a water repellent sandy soil 2. Dynamics of fingered flow. Water Resources Research, 30(9), 2519-2531. https://doi. org/10.1029/94WR00750

Saldanha Vogelmann, E., Miguel Reichert, J., Prevedello, J., Oladele Awe, G., José Reinert, D. (2015). Soil hydrophobicity: comparative study of usual determination methods. Ciência Rural, 45(2), 260-266. https://doi.org/10.1590/0103$8478 \mathrm{cr} 20140042$

Schindler, U., Durner, W., von Unold, G., Mueller, L., Wieland, R. (2010). The evaporation method: extending the measurement range of soil hydraulic properties using the airentry pressure of the ceramic cup. Journal of Plant Nutrition and Soil Science, 173, 563-572. https://doi.org/10.1002/ jpln.200900201

Schindler, U., Doerner, J., Mueller, L. (2015). Simplified method for quantifying the hydraulic properties of shrinking soils. Journal of Plant Nutrition and Soil Science, 178, 10 str. https://doi.org/10.1002/jpln.201300556

Schindler, U., Müller, L., Eulenstein, F. (2015). Measurement and evaluation of the hydraulic properties of horticultural substrates. Archives of Agronomy and Soil Science, 62(6), 806-818. https://doi.org/10.1080/03650340.2015.1083982

Schwärzel, K., Renger, M., Sauerbrey, R., Wessolek, G. (2002). Soil physical characteristics of peat soils. Journal of Plant Nutrition and Soil Science, 165, 479-486. https:// doi.org/10.1002/1522-2624(200208)165:4<479::AIDJPLN479>3.0.CO;2-8
Smith, D. L. (1987). Rockwool in Horticulture. London, UK: Grower Books.

Smith, D. L. (1998). Growing in Rockwool. London, UK: Grower Books.

Team, R.D.C. (2008). R: A Language and Environment for Statistical Computing. R Foundation for Statistical Computing, Vienna, Austria.

Urrestarazu, M., Guillén, C., Mazuela, C. P., Carrasco, G. (2008). Wetting agent effect on physical properties of new and reused rockwool and coconut coir waste. Scientia Horticulturae, 116(1), 105-108. https://doi.org/10.1016/j.scienta.2007.10.030

Vaz, P. M. C., Calbo, G. A., Porto, F. L., Porto, H. L. (2013). Principles and Applications of a New Class of Soil Water Matric Potential Sensors: The Dihedral Tensiometer. Procedia Environmental Sciences, 19, 484-493. https://doi. org/10.1016/j.proenv.2013.06.055

Wu, Y., Zhang, N., Slater, G., Waddington, M. J., de Lannoy, C. L. (2020). Hydrophobicity of peat soils: Characterization of organic compound changes associated with heat-induced water repellency. Science of the Total Environment, 714, 15 str. https://doi.org/10.1016/j.scitotenv.2019.136444

Zamljen, T., Zupanc, V., Slatnar, A. (2020). Influence of irrigation on yield and primary and secondary metabolites in two chilies species, Capsicum annuum L. and Capsicum chinense Jacq. Agricultural Water Management, 234, 7 str. https://doi.org/10.1016/j.agwat.2020.106104 